\title{
Private Wealth Accumulation in Eighteenth Century Scania
}

Intergenerational credit businesses and rural debt logic in Oppmanna

Anders Perlinge

This study sets out from the empirical observation that eighteenth century farmers in north-eastern Scania, in the very south of Sweden, began accumulating financial wealth in the form of both public banknotes and private promissory notes. Based on a kind of fractional reserve banking, banknotes were obviously used to guarantee a more extensive issue of private promissory notes, which at the same time served as legal tender or means of payment in the local area. This is an examination of how these farmers emerged in Oppmanna parish and how they invested and passed on the return on the money they lent to their sons and daughters. The research question thus focuses on creditors and how they operated, as well as how potential borrowers knew about available funds in their local community. The credit business was directly tied to the number of banknotes in local circulation, particularly during the inflationary period of the $\mathrm{r} 76 \mathrm{os}$ and excessive issue of credit notes by the National Debt Office ("Riksgäldskontoret") in the I79os. The need to finance Sweden's wars with Prussia and Russia was in both cases behind monetary policies. ${ }^{\mathrm{T}}$

The aim is to reach a more profound understanding of the importance of credit and its machinery for private capital accumulation in the countryside, long before the establishment of banks or other institutes serving this purpose. The sources are probate, church and judicial records. Members of the same family are followed, which had male heads of household who acted as elected lay assessors ("nämndemän") in four subsequent generations.

Unlike their more well-known capitalist counterparts, the wealth of the farmers was not always fully visible as cash or valuables. Their consumption was culturally determined, thus very different from that of the upper classes or local clergy. They invested primarily in land and farmsteads. The head of the household and his wife sought to leave respectable, well-balanced assets to their sons, daughters and/or sons-in-law. Widowers could remarry and reasonably hope to accumulate additional wealth. Even though farmers did not engage in conspicuous consumption in the same manner as the upper classes, the community was obviously acutely aware of their fortunes. 
Even if the late nineteenth century is regarded as decisive with regard to the permanent shift in focus of the credit market from the private to the institutional sector, with banks serving as agents rather than single individuals, the credit market as the prime instrument of private capital accumulation had operated since long before. However, the specific function of credit businesses from an intergenerational perspective needs more attention than seen in previous research in order to enhance our understanding of the institutionalisation process of the credit market that was to follow, seen in a longer perspective. ${ }^{2}$

\section{The premises of private lending operations}

In pre-industrial societies, there were basically two kinds of paper money constituting the primary stock of money besides coins: official banknotes and private promissory notes. The former had been allowed by the government to increase in volume from the I740s, which ignited banknote-related inflation. Its volume continued to expand during the expansive foreign policy of the political party known as the Hats. The monetary reform of 1776 temporarily accomplished the desired effect of diminishing the volume of banknotes in order to stabilise and restore the value of the Swedish currency against foreign countries. However, it was only to be succeeded by a vast amount of credit notes issued by the National Debt Office in the r79os. These notes drove regular banknotes issued by the National Bank ("Rikets Ständers Bank") out of the market according to Gresham's law. ${ }^{3}$

At the same time, people in a rural community like Oppmanna could use their locally circulated private promissory notes as means of payment and hence create a larger credit volume by themselves. The development in the eighteenth century obviously presented an opening for the use of further promissory notes, which expanded accordingly. General monetary policy and its effects also affected Oppmanna. This was not an isolated peripheral area in that sense. The local credit market exhibited sensibility to national monetary policies, which could be expected in any particular place. People with banknotes simply used them as collateral for their own businesses of borrowing and lending in the local credit market with promissory notes as their instruments. Thereby, a preparedness to honour their obligations with cash was created, as well as to pay taxes or buy land.

The financial alternatives to investing in the local credit market via promissory notes were not legion: there was no bank in the vicinity willing to accept public deposits. And to immediately use the banknotes would result in their owners losing at least half of their purchasing power, since they were able to increase their credit to at least such a degree. Promissory notes 
were also interest-bearing. This behaviour was facilitated by the fact that most countryside households did not show any particularly great interest in conspicuous consumption at this time.

The "great power" of credit served as a kind of machinery due to the fact that the outcome from these sorts of lending operations outnumbered that of general economic growth in pre-industrial societies. In Sweden, the economic growth was less than 0.5 per cent until I850. ${ }^{4}$ It has been argued that the historical experience from the entire pre-industrial period in the West shows that "the law of inequality" was valid: during a period of slow economic growth, the return from capital was obviously and enduringly higher, credit interests were normally at 5 or 6 per cent. This relationship is expressed as $r>g .5$ This may at first not come across as especially remarkable, but it is not something self-evident but a historical experience, and its implications are powerful in the daily life of individuals. In these kinds of societies, inherited wealth was a decisive driver of economic inequality, where some chosen few individuals, households or families had the opportunity to accumulate wealth. It became a sort of "inheritance society", where the owners of capital only needed to reinvest one fifth of their annual return of capital to be able to secure its growth over time. When this capital was sufficiently large, this could be more important than wage earnings, not least in the countryside.

From a societal perspective, this rural debt logic behaviour was important. Farmers took on a modernising function as they contributed to the spread of monetary economy: the use of private promissory notes as local means of payment needed slow volatility or few transactions to work and in the meantime, public banknotes were collected. After a downturn in the early nineteenth century, the influence of private promissory notes continued to play a decisive role in the Swedish economy. This might be explained by the fact that sellers of goods could get a premium on their prices if they were able to offer their buyers different forms of credit. ${ }^{6}$

\section{Contemporary personals on rentiers}

A research question of special interest concerning financial operators, money lenders or rentiers is whether and, if so, how these were singled out by contemporary people. Did these individuals distinguish themselves from others in any form that would have made them visible to potential money borrowers. How did people know where to find funds? Only a very small number of available sources have anything to inform us about this.

One possibility of detecting at least something about these inter human relations in a local community seems to be the personals on local people 
written by the vicars. These are to be found in the death and funeral records of the parish. The term "obituary" is not used here, as this refers to texts intended to immediately become public. The additional fact that vicars often found themselves to be a kind of "agrarian prophets", at times also authors of their parish history, makes them rare contemporary witnesses with specific interests in the lives of farmers. According to Swedish sociologist Börje Hanssen, these personals may be viewed as written testimonies of recurrent urbi-pagan encounters, documented post mortem by vicars and thus offering a form of traces from the past otherwise invisible and fallen into oblivion. These encounters were theoretically found in everyday life within the specific social activity fields of the individuals. These fields, in turn, are "the spatially defined summary of that social activity which characterizes people within a certain group or which interlinks individuals within different groups with one another. A social activity field is not the same as a specific part of the geographical surface [...] Instead it consists of the normally latent inter-human relations." In reality, it is a matter of the actual moment when two individuals interact that forms the current activity field. Hence, it is not to be mistaken for "the city" (urban) or "the countryside" (pagan), but rather a process that is ongoing in the living minds.

The Swedish canon law of 1686 prescribed how notes in death and funeral records should be designed. The law was thus interpreted in such a way that the vicars were intended to write short biographical data - or personals about their deceased parishioners. ${ }^{8}$ From a very early stage, it set a trend on how to formulate these, both in shape and content. From 1747, it was decreed that the names of the deceased's parents should be stated; however, in practice this remained uncommon. The purpose of other information, such as age and cause of death, was related to statistical reasons and thus adjusted to the forms in use by the authority in question ("Tabellverket"). Normally, no parishioners but the parish clerk had access to the church records, thereby enabling the vicars to feel quite free to write just about anything. Considering the unembellished nature of their contents, reasonably any oral commemorative words on the deceased at the funeral service would have been rather different from the written versions. ${ }^{9}$ In Denmark, of which Scania formed part until 1658 , the same procedure was put into practice, although earlier than in Sweden since the canon law of Denmark is forty years senior to the Swedish. ${ }^{\text {10 }}$

In Oppmanna, there was especially one vicar who made these kinds of more specific personal notes: Petrus Neosander, active in $1746-\mathrm{I} 784$. His predecessor, Vicar Hans Widing active in $1689-\mathrm{I} 744$, also had made these kinds of notes; however, rarely with more intimate judgements. There are some interesting exceptions, though, so it was obviously a practice that his 
successor could use as a model and further develop during his own period of service. ${ }^{\text {II }}$

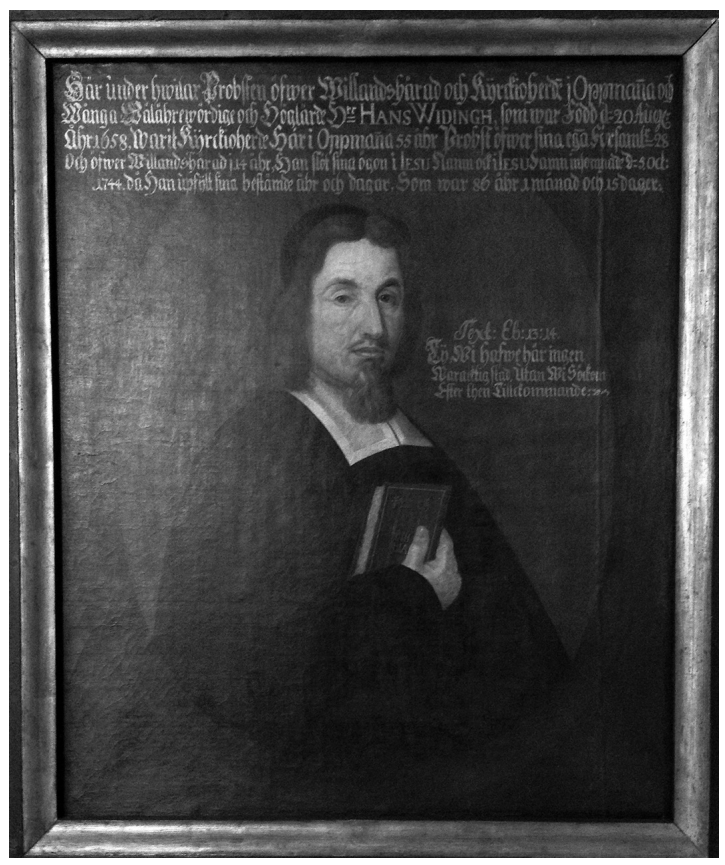

Hans Widing's portrait by Alexander Jungner in Oppmanna church. Photo: Author.

Hans Widing was the son of an assistant judge at the district court in Bosjökloster and son-in-law of his predecessor, Vicar Niels Olufsen Löderup. Widing was considered "a rich and well-meaning man" and appreciated by his parishioners. His long period of service was apostrophised in a sermon after his passing by no less than the Bishop of Lund, Henrik Benzelius, personally present in Oppmanna church on this special occasion in December I744. ${ }^{\text {I2 }}$

Petrus Neosander, on the other hand, was of peasant stock. His father was a farm tenant in Klagstorp in the neighbouring parish of Näsum. But the son was educated and learned by experience in both Lund and Stockholm. He arrived, still rather young, to Oppmanna and Vånga by prescription of Adolf Fredrik, successor to the Swedish throne, after being elected by the parishioners in an election on 3 November $1745 .{ }^{13}$ In Oppmanna, Neosander led a quiet and unnoticed life during his 38-year period of service, and he and his wife Birgitta Wedege received a fine posthumous reputation on an epitaph. 


\section{Private capital accumulation in the countryside}

A qualitative way of analysing money lenders in the countryside is to commence with some interesting individual example and then follow up what happens from an economic point of view in subsequent generations of the same family. This would be different from famous finance families, who have accumulated great wealth they then transfer to the next generation with the assistance of different techniques. Activities of economically active people in the countryside do not in a similar manner result in a corresponding vast accumulation of visible pecuniary wealth. Outside of the cities, and before industrialisation, investment in farmsteads and land was the most important instrument in order to secure economic transfers over generations. It was not merely a matter of the eldest son's inheritance of the family farm according to primogeniture principles. It was also a matter of being able to include all other children, daughters as well, to have a part of the assets. This was often accomplished through matrimonial strategies and pure matchmaking, at least among freeholders. ${ }^{14}$

One individual who appears from the past variety of financial operators in the hundred of Villand in the eighteenth century, found while doing some other historical research on this geographical area, was a member of the second generation of a line of lay assessors, Trued Nielsson, born in Oppmanna in 1677 . His father, Niels Jepsson, had become fatherless by the age of seven and grew up together with his mother and siblings in Osby parish in the adjacent hundred. In the r67os, he married for the third time and lived on a farm in Hillehaga, where Trued was born. Obviously, there must have been capital available in the family since Niels figures recurrently as a creditor in the local court. He passed away of old age in 1708 after going blind three years earlier. ${ }^{15}$ Trued Nielsson purchased the farmstead No. io Oppmanna, today known as "Hillingagården", already at the age of twenty. Sellers were the heirs-at-law after former Parish Vicar Niels Olufsen Löderup, active between I653 and I689. The transaction was questioned for legal reasons but settled in favour of Trued Nielsson. ${ }^{16}$

Trued was elected church warden in 1705 . However, three years later a conflict of some kind appeared with the new vicar, Hans Widing, and

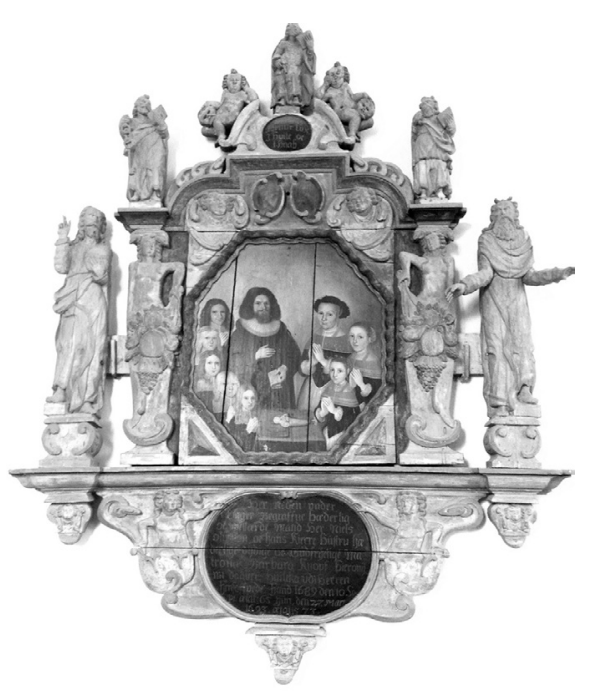

Vicar Niels Olufsen Löderup with his family, epitaph in Oppmanna church. Photo: Author. 
the former was fined 4 daler silvermynt by the church for "abusive writing against his clergyman". ${ }^{17}$ As lay assessor of the county court in Fjälkinge, Trued Nielsson would become a prominent figure. It did not serve his posthumous reputation well. He was sworn in as lay assessor in I712, succeeding one of the victims of the devastating plague epidemic. ${ }^{18}$ The very same year set off what would become a long series of trials with Trued Nielsson acting as both plaintiff and defendant. He was, for example, accused of theft by a farmer. He would also be fined for "charging with false accusations" against other farmers and furthermore for scuffles and threats.

With remarkable frequency, his conflicts were associated with credit activities, in these cases without exception with himself as a plaintiff. No one ever summoned him in a debt litigation. ${ }^{19}$ In the late winter of ${ }^{7} 729$, he was once again summoned to court due to a scuffle. ${ }^{20}$ In short, the story was this: on Sunday ${ }_{23}$ February, he assaulted and slapped farmer Påhl Persson just outside his own farm, where churchgoers were gathering before the sermon. They had a disagreement about a claim that Trued had on Påhl, and Trued used his walking stick to hit him. Several witnesses were able to confirm these events. The court decided to fine Trued Nielsson 13 daler silvermynt for abuse, the double amount for breaking the Sabbath by bringing his claim up on Sunday just in time before the sermon.

Trued Nielsson was most certainly known as an industrious money lender in the local credit market in Oppmanna and its surroundings. He often appeared in court, most frequently because he wanted to collect outstanding claims. From the autumn session of the court in $\mathrm{I} 723$ to the winter session in $\mathrm{I74}$ I, he acted in 23 such cases, in total collecting some 250 daler silvermynt. ${ }^{21}$ His lending activities commonly consisted of rather small amounts, some 2-30 daler silvermynt. Borrowers were not limited to Oppmanna but included farther parts of Villand's hundred and typically included farmers, soldiers or craftsmen.

Possibly, some of the conflicts Trued Nielsson was drawn into might have something to do with his increasing deafness. Due to his hardness of hearing, he was dismissed from the court as lay assessor in $\mathrm{I}_{732}$ and replaced by his eldest son Anders Truedsson, Södra Staversvad (Oppmanna). Another son, Nils Truedsson, later certified that "on top of that, the old man was hard to please". ${ }^{22}$

Just after his withdrawal as lay assessor, Trued Nielsson was once again summoned to court by Vicar Hans Widing, among others. This time, it was because he "through violent actions had obstructed and hampered operations at Oppmanna saltpetre works". ${ }^{23}$ His falling out was based on the simple fact that staff at the works had chosen to use equipment in the production other than the equipment he owned. In this context, he had brought with 


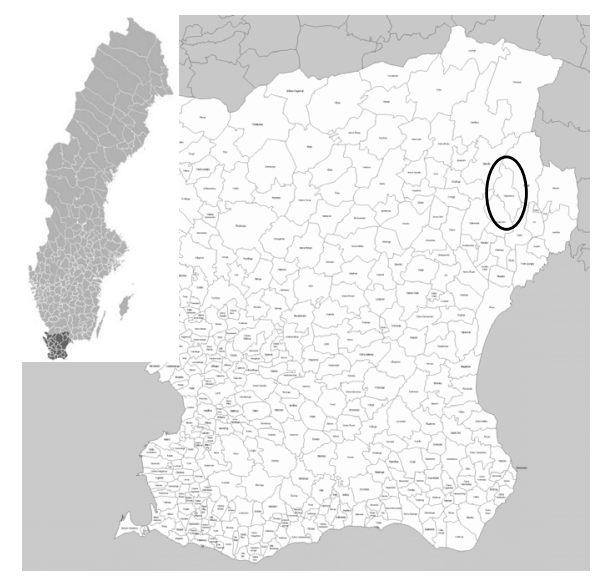

Oppmanna parish in the north-eastern corner of Scania in southern Sweden.

him some silver spoons, which he hammered into the ground, and a golden chain and a moneybag filled with coins that he showed to foreman David Månsson, whom he ironically referred to as "King David", to show his importance in a pompous manner. Accompanied by his son, Jon Truedsson, he had also been threatening and told David Månsson that "the Devil would be put into him". Once again, Trued Nielsson was fined, this time the vast amount of roo daler silvermynt, including economic compensation for lost production. Hans Widing noted in his personal on Trued Nielsson, when he after a fierce illness eventually passed away in I744, that he had accumulated "great wealth" but that his faith was not exemplary. ${ }^{24}$ It should be safe to assume that Trued Nielsson is a concrete example of what Börje Hanssen argued could be a possible effect of the economic disassociation of individual farmers from their class peers. They were supposedly mean and greedy and looked upon with a stern view, formally respected but maintaining a certain distance from their borrowers. ${ }^{25}$

The probate inventory after Trued Nielsson shows, through the absence of live animals and real estate, that most of his assets were already distributed to his heirs-at-law. The remaining parts were furthermore bequeathed away to his youngest son, Nils Truedsson, and there was only 9 daler (henceforth: $d s m)$ I6 öre silvermynt in cash and seven claims on promissory notes in the amount of $446 \mathrm{dsm}$ from individuals living outside Oppmanna. This was equivalent to half the estate. He was still active in the credit market, however, away from his home parish. There were also silver objects worth I77 dsm. The minor debts of $28 \mathrm{dsm}$ were all linked to funeral costs and probate inventory. ${ }^{26}$ 
Niels Jepsson, copyholder (ch), lay assessor (la) [3 marriages] Hillehaga 1 1619-1708

\begin{tabular}{|c|c|c|c|c|c|}
\hline & & \multicolumn{2}{|c|}{$\begin{array}{l}\text { Trued Nielsson, la [2 marriages] } \\
\text { Oppmanna } 10 \\
1677-1744, \text { probated }(\mathrm{p})\end{array}$} & \multicolumn{2}{|c|}{$\begin{array}{l}\text { Jon Nielsson, la [2 marriages] } \\
\text { Hillehaga } 1 \\
\text { 1679-1743, p }\end{array}$} \\
\hline $\begin{array}{l}\text { Anders Truedsson, la } \\
\text { [4 marriages] } \\
\text { Södra Staversvad } \\
1704-1777, \mathrm{p}\end{array}$ & $\begin{array}{l}\text { Jon Truedsson, la } \\
{[3 \text { marriages }]} \\
\text { Oppmanna } 10 \\
1708-1766, p\end{array}$ & $\begin{array}{l}\text { Nils Truedsson, ch } \\
{[2 \text { marriages] }} \\
\text { Oppmanna } 11 \\
1726-1769, \mathrm{p}\end{array}$ & $\begin{array}{l}\text { Kirstin Truedsdotter } \\
{[1 \text { marriage }]} \\
\text { Grönhult } 2 \\
1702-1793\end{array}$ & $\begin{array}{l}\text { Bengta Truedsdotter } \\
\text { [1 marriage }] \\
\text { Tegelgården } \\
1710-1778\end{array}$ & $\begin{array}{l}\text { Svenborg Truedsdotter } \\
{[1 \text { marriage }]} \\
\text { Viby } 3 \\
1717-1758, p\end{array}$ \\
\hline $\begin{array}{l}\text { Children of passed daughter: } \\
\text { Per Oredsson, la } \\
\text { Nils Oredsson } \\
\text { Trued Oredsson } \\
\text { Ola Oredsson } \\
\text { Anders Oredsson } \\
\text { Bolla Oredsdotter } \\
\text { Truen Oredsdotter } \\
\text { Nilla Oredsdotter } \\
\text { Anna Oredsdotter }\end{array}$ & $\begin{array}{l}\text { Widow Catharina Kock } \\
\text { Sons-in-law: } \\
\text { Niklas Bengtsson } \\
\text { Måns Månsson } \\
\text { Sven Niklasson } \\
\text { Sven Truedsson } \\
\\
\text { A son of Jon Truedsson's: } \\
\text { Trued Jonsson, la } \\
\text { 1750-1823 } \\
\text { Oppmanna } 10\end{array}$ & $\begin{array}{l}\text { Widow Malena Jönsdotter } \\
\text { Truen Nilsdotter } \\
\text { Anna Nilsdotter }\end{array}$ & $\begin{array}{l}\text { Passed husband Oluf Mattsson, } p \\
\text { Masse Olufsson } \\
\text { Nils Olufsson } \\
\text { Anders Olufsson } \\
\text { Ored Olufsson } \\
\text { Svenborg Olufsdotter } \\
\text { Gunnel Olufsdotter } \\
\text { Truen Olufsdotter } \\
\\
\text { Children of Truen Olufsdotter: } \\
\text { Ored } \\
\text { Truen }\end{array}$ & $\begin{array}{l}\text { Passed husband Anders Stenkilsson, } p \\
\text { Stenkil Andersson } \\
\text { Trued Andersson } \\
\text { Sven Andersson } \\
\text { Nils Andersson } \\
\text { Bengta Andersdotter } \\
\text { Ingar Andersdotter } \\
\text { Kierstina Andersdotter }\end{array}$ & $\begin{array}{l}\text { Widower Ake Abramsson, } p \\
\text { Abram Åkesson } \\
\text { Sven Åkesson } \\
\text { Nils Åkesson } \\
\text { Ola Åkesson } \\
\text { Pär Åkesson } \\
\text { Ingar Åkesdotter }\end{array}$ \\
\hline
\end{tabular}

Genealogical table. Sources: Oppmanna kyrkoarkiv, död- och begravningsböcker 1708-1823 (LLA); Villands häradsrätts arkiv, bouppteckningar, huvudserien, 1743-1794, serie Flla (LLA).

The colourful and, according to his contemporaries, admittedly troublesome Trued Nielsson was a member of the second generation of lay assessors belonging to the same family circle and very active in the local credit market in Oppmanna. Thus, he was one of the founders of a line of financially influential individuals that would last for several generations in the same area. His younger brother, Lay Assessor Jon Nielsson, also made use of the local credit market to further his wealth. The number of litigations about debts, however, were fewer than those of his brother. From the summer session of the court in 1728 to the winter session in 1736 , there were Io cases. ${ }^{27}$ Contrary to his brother, Jon Nielsson did not have any personal written by Vicar Hans Widing. Aged 64, he died in I743, leaving a pregnant wife behind, who later gave birth to a daughter. ${ }^{28}$

The probate inventory after Jon Nielsson, however, is a more impressive document than that of his brother. ${ }^{29}$ There was cash in the amount of ${ }_{5} \mathrm{I} d s \mathrm{~s}$ and silver objects worth $97 \mathrm{dsm}$. The 52 financial claims, in total amounting to more than 2,8I $7 \mathrm{dsm}$, represented a value close to 60 per cent of the estate's gross wealth. Single claims could be as much as $200-300 \mathrm{dsm}$, but smaller amounts generally dominated. His debtors belonged to certain categories: a vicar, watchmaker, tailor, blacksmith, baker, goldsmith and military men along with an unmarried noble woman and several farmers and crofters.

The second eldest son of Trued Nielsson, Lay Assessor Jon Truedsson, was even more active in the local credit market than his father and uncle. 
His probate inventory accounts for cash in the amount of $\mathrm{I} 6 \mathrm{I} d s m$ and silver objects worth more than $840 \mathrm{dsm}$. The I33 claims, in total amounting to more than II,700 dsm, were the equivalent of 80 per cent of his gross wealth. The value of the real estate, No. ro Oppmanna, was $800 \mathrm{dsm}$. Debts amounted to $4,529 \mathrm{dsm} .^{3 \circ}$ This made his wealth in current prices even somewhat greater than the wealth of Vicar Hans Widing, whose estate he had appraised some twenty years before. The well-informed Vicar Jöran Johan Öller offers a rare, almost contemporary, perspective of this in his narrative on the nearby parish of Jämshög (Blekinge county) by end of the eighteenth century. Öller obviously used several sources, including personal knowledge from the parish where he arrived in the late i77os. Even if one might suspect that the text is to some extent stereotyped, it reasonably expresses his own opinion: $:^{3^{1}}$

A farmer who lives here and who owns a reasonably good farmstead and a couple of hundreds or topmost 3 or 4,0oo daler silvermynt in interest is said to be very rich. This is believed particularly because the farmer living here only rarely lacks money, and whenever needed, he is able to pay for his taxes and imposts. Partly, this has to do with his constant business among those who have something to sell, especially timber and cattle. Partly, it has also to do with his mutual helpfulness to assist the less wealthy and poor in distress with necessary credit, every day and hour when it is urgent.

I knew a farmer who was thought to be immensely rich and claimed to have 60,000 daler silvermynt in interest, which in such case undoubtedly would have made him the richest of his time in the parish. But during the probate inventory following upon his death, it was found that in reality merely between 7 or 8,ooo daler silvermynt was the entire outstanding sum in interest, and perhaps a couple of hundreds ditto remaining. However, he owned nice real estate and a lot of personal property, which together did not raise to half, though, of the sum he was thought to have as outstanding claims against interest alone.

In a similar way, Jon Truedsson, like his uncle, operated a credit business within a quite extensive network, including urban individuals. Besides several farmers, debtors were also found in the two most nearby towns: Kristianstad and Sölvesborg. Single claims could be hundreds of $d s m$. He also kept a special ledger of his minor debtors, in addition almost $200 \mathrm{dsm}$. One single claim was as much as $800 \mathrm{dsm}$, which possibly implies that he was prepared to take on higher risk or might reflect some recent real estate transaction. His unusually large number of urban economic relations in Kristianstad might be related to his third wife, Hilla Catharina Kock. She was widowed after parish clerk Håkan Holm, but her family was part of 
a completely different kind of network than people in the countryside in general. Her father, Rasmus Kock, was the manager of a noble estate and had been a scribe at the horse regiment of southern Scania. Her uncle was a cavalry captain. Both were sons of wholesaler Jöns Kock in Ystad, on the south coast some roo kilometres away.32

It is plausible that some of the remarkably huge capital Jon Truedsson had at his disposal somehow originated from his wife Hilla Catharina Kock. The probate inventory after his first wife, Kerstin Svensdotter who passed away in 1750 , accounts for merely four claims of $250 \mathrm{dsm}$, cash in the amount of $400 \mathrm{dsm}$, and there were no recorded debts. The farmstead was appraised at $500 \mathrm{dsm}$, and there were silver objects worth $202 \mathrm{dsm}$. The gross wealth was 2,074 $d s m .^{33}$

Every single year with a block of financial claims of II,700 dsm, Jon Truedsson was thus able to collect interest of more than $700 \mathrm{dsm}$, assuming an interest at 6 per cent, not counting possible credit losses. He thus ought to be found among the richest commoners in the county by that time. This was noticed by Vicar Petrus Neosander when he summarised the course of Jon's life in the personal, stating that he was brought up by very wealthy parents and in his lifetime became a rich and wealthy man with a lot of worldly possessions. However, in addition to that, he was rather awfully tempered, mean and greedy. ${ }^{34}$ No beautiful ending of that life story. However, four years later, on the passing of his widow Hilla Catharina Kock, her personal stated about him that he was "Lay Assessor Clever Jon Truedsson", with whom she had lived in a tight marriage without heirs and "led a gentle and meek life". 35

The youngest of Trued Nielsson's sons, Nils Truedsson, was a tenant farmer at No. II Oppmanna and active in the local credit market, just like his relatives. His credit business, however, seems to have been limited, and the personal is more focused on his tragic life story. His troubled life showed more of blasphemy than of any virtue, the vicar concluded. He was a rich, prosperous and hard-working man, but rather grudging to live with. He led a bad life in daily conflict, scuffles and disputes with both his wives, and he was a severe father towards his children and servants. His restless mind in later years was also affected by drunkenness. ${ }^{36}$

Nils Truedsson's probate inventory accounts for cash in the amount of I57 dsm, 20 claims in the total amount of $643 \mathrm{dsm}$ or 22 per cent of the gross wealth and silver objects worth more than $800 \mathrm{dsm}$. Debts were ${ }_{5} 58 \mathrm{dsm} .{ }^{37}$ His debtors were mostly country folk, and single amounts were some tens of $d s m$. His credit business exhibited a more limited network than that of his brother, but he obviously lived I5 years longer. There was no reported real estate value since he was a tenant farmer, not a freeholder like his brother. 
His widow, Magdalena Jönsdotter, remarried two years later with the farmer Nils Åkesson, and they continued the management of No. II Oppmanna but were childless. On her passing, aged 73 in I793, all property went to her husband except a sum of $500 \mathrm{dsm}$, which was reserved for her two surviving daughters of the first marriage with Nils Truedsson..$^{3}$ The estate was appraised by lay assessor Trued Jonsson, a nephew of the first husband. The gross wealth was I, $838 \mathrm{dsm}$, of which there was silver worth $43 \mathrm{dsm}$ and five financial claims worth $227 \mathrm{dsm}$. The debts were $657 \mathrm{dsm}$, of which roo $d s m$ was a promissory note loan by Trued Jonsson.

Anders Truedsson, the eldest son of Trued Nielsson and his successor as lay assessor at the county court in Fjälkinge and furthermore to become district rural judge, managed to escape from a vicious personal, just like his uncle Jon Nielsson. In $\mathrm{I} 777$, his probate inventory accounts for cash in the amount of $2 \mathrm{dsm}$, claims at $886 \mathrm{dsm}$ or I8 per cent of the gross wealth. There were only small numbers of silver objects worth I2 $d s m$, and debts were limited to $30 \mathrm{dsm}$. The real estate in Södra Staversvad had recently been disposed of for $550 \mathrm{dsm} .^{39}$

Among Trued Nielsson's daughters, the probate inventory has only been preserved after the youngest and first deceased, Svenborg Truedsdotter. In her estate, there was no cash, but silver objects worth $45 \mathrm{dsm}$. The I8 claims all together amounted to $276 \mathrm{dsm}$, or 20 per cent of the gross wealth. Debts were $48 d s m .4^{\circ}$ Her husband was Lay Assessor Åke Abramsson at No. 3 Viby, some 20 kilometres south of Oppmanna. His probate inventory was made in 1784 but remained unregistered for ten years. By then, there had been auctions in $\mathrm{I} 784-\mathrm{I} 785$, but the estate division was not carried out until I794. ${ }^{{ }^{\mathrm{I}} \mathrm{H}} \mathrm{He}$ had gotten remarried to Bereta Olasdotter, and the statement deviates from the others in several ways. There was only cash in the amount of $2 d s m$, while the value of silver objects was Io3 $d s m$. No financial claims were reported, and the real estate was appraised at I,404 $d s m$. Debts were I,592 dsm, distributed on 32 creditors, and the gross wealth was 2,880 dsm.

Another daughter, Kirstin Truedsdotter, married freeholder Oluf Mattsson at No. 2 Grönhult (Vånga), who was probated in $1753 .{ }^{42}$ He was one of a limited group of "parish bankers" in Vånga and also a prominent proto-industrial entrepreneur, based on the natural resources of his farm, and an active exporter of stone products from his quarry to continental Europe. ${ }^{43}$ The probate inventory shows cash in the amount of $42 d s m$ and silver objects worth II $3 d s m$. The 26 financial claims were all together in the amount of 3,216 dsm, or about 70 per cent of the gross wealth. Among these claims, one $80 \mathrm{dsm}$ promissory note was signed by Vicar Petrus Neosander. There were also other claims on urban people, and the real estate was appraised at $300 \mathrm{dsm}$, while debts were appraised at I,IO4 $\mathrm{dsm}$. 
After the passing of dependent lodger Anders Stenkilsson at Tegelgården in nearby Österslöv parish, on the southern side of Lake Oppmanna, a probate inventory was made in $1775 .{ }^{44} \mathrm{He}$ had been married to Trued Nielsson's daughter, Bengta Truedsdotter, who had now become a widow. The estate had no cash but silver objects worth $48 \mathrm{dsm}$. A single claim of $2 d s m$ was reported among the gross wealth of $364 \mathrm{dsm}$. There was no real estate involved, and the debts amounted to $67 \mathrm{dsm}$.

Probated assets and debts within this line of lay assessors and their families are summarised in the figure below.

In the middle of the figure, Jon Truedsson of the third generation stands out considering the volume of his credit transactions. Financial claims of

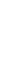
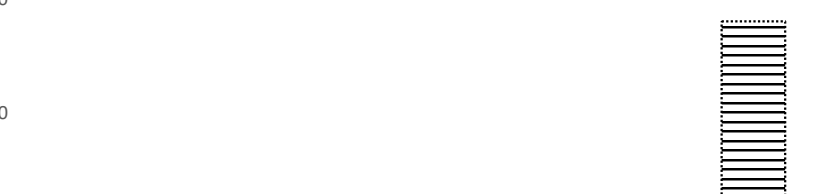

(1)


this kind, however, were the most decisive part of private wealth of an additional four members of this family circle. It can be noticed that their debt quotas were quite moderate at the time of death. The largest debts (below the zero line) were linked to Jon Truedsson, but still did not exceed one third of his gross wealth.

\section{The property left by the vicars: a comparison}

Vicar Hans Widing passed away late in I744, the same year as Trued Nielsson. Probate inventory appraisals were made by his son, Jon Truedsson. ${ }^{45}$ This serves as a good illustration of the cultural differences between common folk and gentle folk regarding their consumption patterns. In Widing's household, with a gross wealth of 9,066 dsm, there was cash in the amount of $108 \mathrm{dsm}$, gold and jewels worth $700 \mathrm{dsm}$, which is hardly ever found among commoners, and silver objects worth I, 3 I $7 \mathrm{dsm}$, which is more than among normal farmer households. Outstanding financial claims amounted to 3,894 $d s m$, or 43 per cent of the gross wealth. Huge amounts, each more than I,ooo $d s m$, were lent to three noblewomen, while only smaller amounts were lent to farmers and clergymen in Oppmanna and its closest surroundings. The real estate had already been transferred to his wife during his lifetime, and ten debts amounted to 3,009 $\mathrm{dsm}$.

The property left by Vicar Petrus Neosander was accounted for on his passing in $1784 .{ }^{46} \mathrm{His}$ personal economic position was much more modest than that of his predecessor. Of the gross wealth of $\mathrm{r}, 830 \mathrm{dsm}$, silver objects were worth $225 \mathrm{dsm}$. Outstanding financial claims were nothing but accrued pastoral tithes, and seven debts amounted to I,518 $\mathrm{dsm}$. The appraisement was carried out by a grandson of Trued Nielsson, lay assessor Trued Jonsson in Oppmanna.

The relations between members of the lay assessor family circle in Oppmanna and the parish vicars were obviously intertwined - until death did them part.

\section{Conclusion}

The theoretical subject of this paper has been to search for a deeper understanding of the machinery of credit and its function for comprehensive private wealth accumulation in the countryside, long before the establishment of banks or other institutes.

The volume of private lending operations based on private promissory notes seems to have been correlated with the amounts of public banknotes 
and credit notes in local circulation, thus becoming the most vivid in the i76os and I79os.

The first research question concerned how potential borrowers knew where to find funds in their local community. Further analyses of how these creditors, notably farmers, were singled out in Oppmanna seem to indicate that their credit businesses and personal wealth were well-known to people in the local community. Parish vicars documented personals about them on their passing certifying this, at times with vicious comments not rarely with religious undertones.

The second research question concerned the investment patterns over generations, which has been a theme receiving less focus in previous research. Probate inventories from a line of lay assessors in the same family circle in Oppmanna illustrate how financial returns, obviously earned on money lending besides of farm produce or proto-industrial activities, were invested in land and farmsteads. This wealth was passed over generations, including both sons and daughters. There was obviously a specific debt logic among the farmers for that purpose, to voluntarily help balance the principle of male primogeniture, even long before formal legislation acknowledged female equality with regard to inheritance in the countryside in I845.

The many silver objects that can be found in the estates may indicate a parallel and probably older, traditional form of investment pattern. Another probable reason for keeping such items would be to have dowries ready for their daughters, morning gifts for their consecutive wives or simply to use silver items to borrow money when needed against collateral.

The accumulation of private wealth in the countryside did not result in any famous families with huge visible fortunes. Their wealth was instead ploughed back into land and handed down over several generations, to be held in trust by descendants of the initial generation. Reasonably, besides the intrinsic power of credit as a form of machinery for wealth accumulation, inherited positions based both on money and honorary offices like that of lay assessor contributed to the resilience of the private credit market.

\section{Private Wealth Accumulation in Eighteenth Century Scania Intergenerational credit businesses and rural debt logic in Oppmanna} Empirical observations show that some farmers in north-eastern Scania ("Skåne") in the eighteenth century began to accumulate financial wealth both in the form of public banknotes and private promissory notes. Based on a kind of fractional reserve banking, where collected banknotes were used as a guarantee for a more extensive issue of promissory notes, the latter could, in turn, serve locally as means of payment or a substitute for money. 
Two important research questions in this context include how these farmers were singled out in the local community, thus being known by potential borrowers and how returns obviously earned on money lending were invested and passed over generations including both sons and daughters.

Even though the wealth of certain farmers did not frequently become visible as conspicuous consumption, such as in the upper classes or local clergy, the existence of their fortunes was reasonably well-known. This was depicted by the vicar in his personals on deceased parishioners, which may be regarded as an outcome of urbi-pagan inter-human encounters.

The theoretical subject is a concrete understanding of the importance of this credit machinery for private capital accumulation in the countryside, long before the establishment of banks. The sources are probate, church and judicial records, which are used to follow up individuals within the same family represented by one line of lay assessors ("nämndemän”) over four generations.

Keywords: credits, promissory notes, urbi-pagan encounters, personals, probate inventories, debt litigations

\section{Notes}

The author is grateful to the Foundation for Economic History Research within Banking and Enterprise and the Ebbe Kock Foundation (EK 20I4ooo6) for research funding. He is also grateful for comments from participants in the session on Wealth, Credit, and Banking in Sweden and Finland at the 43rd Economic and Business History Society Annual Conference, University of Jyväskylä, 30 May-2 June 2018, and at the research seminar at EHFF Stockholm School of Economics, 2I August 2018.

I This observation is based on an empirical study of Vanga parish (i.e., in the same combined parish as Oppmanna). Anders Perlinge, "The rise and fall of parish bankers: Paper money and banking in Sweden during the eighteenth and nineteenth centuries", in Monetary Boundaries in Transition: A North European Economic History and the Finnish War 1808-I809. Tuukka Talvio \& Cecilia von Heijne (eds.), Studies/The Museum of National Antiquities, Stockholm, I6, Stockholm 2orob, pp. 6I-80. It seems to correspond with the general money supply (Mo) of the country. Cf. Rodney Edvinsson \& Anders Ögren, "Swedish money supply, I620-2012", in Historical Monetary and Financial Statistics for Sweden, vol. II, House Prices, Stock Returns, National Accounts, and the Riksbank Balance Sheet, I620-20I2. Rodney Edvinsson, Tor Jacobson \& Daniel Waldenström (eds.), Stockholm 2014, pp. 323-325.

2 See, for example, Elise Dermineur (ed.), Women and Credit in Pre-Industrial Europe, Turnhout 2or8; Philip T. Hoffman, Gilles Postel-Vinay \& Jean-Laurent Rosenthal (eds.), Priceless Market: The Political Economy of Credit in Paris, I660-I870, Chicago \& London 
20oo; Philip T. Hoffman, Gilles Postel-Vinay \& Jean-Laurent Rosenthal (eds.), Dark Matter Credit: The Development of Peer-to-Peer Lending and Banking in France, Princeton \& Oxford 2019; Maths Isacson, Ekonomisk tillväxt och social differentiering I680-I860: Bondeklassen i By socken, Kopparbergs län, Stockholm I979; Håkan Lindgren, "The modernization of Swedish credit markets, 1840-1905: Evidence from probate records", The Journal of Economic History, vol. 62, no. 3, 2002, pp. 810-832; Craig Muldrew, The Economy of Obligation: The Culture of Credit and Social Relations in Early Modern England, London 1998; Anders Perlinge, Sockenbankirerna: Kreditrelationer och tidig bankverksambet: Vånga socken i Skåne 1840-1900. Nordiska museets handlingar, I30, Stockholm 2005; Patrick Svensson, Agrara entreprenörer: Böndernas roll i omvandlingen av jordbruket i Skäne ca 1800-1870. Lund Studies in Economic History, I6, Lund 200I.

A rare example of intergenerational analysis in this context is Håkan Lindgren, "Parish banking in informal credit markets: The business of private lending in early nineteenth-century Sweden”, Financial History Review, vol. 24, no. I, 20I7, pp. 83-I02. The term "intergenerational" here simply addresses the fact that this credit business occurred in several subsequent generations in the same family. However, it has been suggested that this was different from this kind of experience in modern family firms, as more of "a consequence of diversification of economic activities deeply embedded in agricultural pursuits. Moreover, financial business was highly dependent on the lifespan of the family head, since outstanding promissory notes were expected to be repaid or reissued in case of death." Lindgren 20I7, p. ror.

3 Niall Ferguson, The Ascent of Money: A Financial History of the World, London \& New York 2008, p. 49; Eli F. Heckscher, Sveriges Ekonomiska Historia från Gustav Vasa: Det moderna Sveriges grundläggning, II:2, Stockholm 1949, pp. 733-8II; Lars Herlitz, "Nordencrantz, Christernin och den monetära debatten på I760-talet", in Riksdag, kaffehus och predikstol: Frihetstidens politiska kultur I766-I772. Marie-Christine Skuncke \& Henrika Tandefelt (eds.). Skrifter utgivna av Svenska Litteratursällskapet i Finland, 649, Stockholm \& Helsinki 2003, pp. 13I-I42; Anders Perlinge, "Parish bankers": Credit relations and early banking: Evidence from Sweden during the eighteenth and nineteenth centuries. Mimeographed paper presented at the 2Ist International Congress of Historical Sciences, Special Theme No. I2, Social History of Credit. Amsterdam 2oroa; Perlinge 2orob, pp. 6I-80.

4 Daniel Waldenström, "Wealth-income ratios in a small, developing economy: Sweden, I810-2014", The Journal of Economic History, vol. 77, no. I, 20I7, p. 288.

5 See, for example, Thomas Piketty, Capital in the Twenty-First Century. Translated by Arthur Goldhammer, Cambridge, Mass. 20I4, pp. 25-27, 30, 244-246, 350-35I, 36I.

6 Börje Hanssen, Österlen: En studie över social-antropologiska sammanhang under I6oo- och I70o-talen i sydöstra Skåne, Stockholm I952, p. I73. An example from a private journal written by a person living close to Stockholm in 1835 indicates that auction prices may increase by some 50 per cent if a three-month credit was offered beforehand. Britt Liljewall, Vackra dagboken: Carl Henric Robsabms anteckningar från I830-talet. Monografier utgivna av Stockholms stad, 259, Stockholm 20I7, p. 47 and footnote 55 .

7 For a theoretical discussion on the situation, see Hanssen 1952, pp. 4IO-4I3. Cf. Perlinge 2005, pp. 30-32, 92-93.

8 Gösta Lext, Studier isvensk kyrkobokföring $1600-1946$. Meddelanden från ekonomisk-historiska institutionen vid Göteborgs universitet, 54, Gothenburg 1984, pp. 156-I57. In the parish Ål, close to Lake Insjön between Gagnef and Leksand in Dalecarlia, vicars kept special books of personalia during the entire period of I767 to i86r. The five volumes contain detailed personals on every deceased adult in the parish, in addition to 
some lines about children. These personal records (Åls kyrkoarkiv, vol. Fr:2-3; FII:I-3, Riksarkivet Uppsala landsarkiv (ULA)) were written besides regular death and funeral records, preserved from $167 \mathrm{I}^{-1695}$ and from 1776 onwards (Åls kyrkoarkiv, vol. Fr:I; Fr:4- (ULA)). In Sweden, there are probably no better detailed series of preserved personals. These might be used for further analyses of the lives of "ordinary" people in that period.

9 Compare, for example, a rarely preserved draft of an obituary notice containing 53 lines regarding the maid Olu Nilsdotter in Vånga I April I75o, obviously intended for public oral presentation in the church since it addresses her surviving next-of-kin. The corresponding personalia in the death and funeral records comprises merely 7 lines. Oppmanna kyrkoarkiv, död- och begravningsböcker I750, vol. C:4, p. 230; ibid., skrivelser och resolutioner, vol. J:2, Riksarkivet Lunds landsarkiv (LLA).

Io Possibly, notes of this kind have been used more extensively in Danish research, albeit with a stronger focus on mental images of the world among vicars than among "ordinary" people. See, for example, Ole Højrup, Levnedsløb i Sørbymagle og Kirkerup

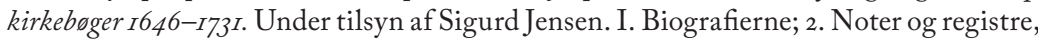
Copenhagen 1963-1968. Cf. Ulf Svarte Bagge \& Tord Jöran Hallberg, Osby kyrkobok 1647-I690. Utgåva I, I995, http://www.ddss.nu/documents/osby.pdf (accessed I8 June 2019).

II Gunnar Carlquist, Lunds stifts herdaminne: Från reformationen till nyaste tid. Ser. II. Biografier. I2. Villands och Gärds kontrakt, Lund 2004, pp. 213-216. Cf. Perlinge 2005, p. 285 .

I2 Henrik Benzelius, Guds barnas tröst, under ett owaracktigt lif, wiszheten, om et tilkommande waracktigt uti en christel. likpredikan då, probsten öfwer Willands härad och kyrkioherden $i$ Opmanna och Wänga ... Hans Widingh, med anständig heder begrofs i: Opmanna kyrka d. ${ }_{12}$ decemb. åbr I744, Lund ${ }_{1745}$. These printed personals (here the term obituary might have been used) merely reflect Widing's education and professional positions. See https://weburn.kb.se/metadata/976/EOD_2400976.htm (accessed I8 June 2019). Henrik Benzelius was appointed archbishop in 1747.

I3 In this election some of this study's protagonists excel. Jon Truedsson at No. Io Oppmanna chose to refrain and "left it to His Majesty's gracious delight", as did one other parishioner. Both of his brothers, Nils Truedsson at No. II Oppmanna and Anders Truedsson in Södra Staversvad, were absent during the election, like a number of other people. Oppmanna församlings arkiv, bilagor till husförhörslängden och församlingsboken, vol. Hr: (LLA). Petrus Neosander became vicar elect with ror votes against 9 and 5, respectively, for his competitors and hence received the royal prescription.

I4 See, for example, Gabriel Kvillner, "En studie i giftermålsfält", Fataburen: Nordiska museets och Skansens årsbok 1969, pp. 6I-72; Jöran Johan Öller, Beskrifning öfwer Jemshögs Sochn i Blekinge, Jämshög 1967 (I800), pp. 212-213.

I5 Oppmanna församlings arkiv, död- och begravningsböcker 1708, vol. Cr:I, p. I25 (LLA). His ancestry can be followed several generations backwards until about 1435 in Osby parish. See https://gw.geneanet.org/jimmyfreij?lang=en\&m=A\&p=trued\&n=nilsson\&oc $=8 \&$ sosab $=10 \&$ color $=\& t=T \& v=9$ (accessed I8 June 20I9).

I6 Göta hovrätts arkiv, Advokatfiskalen Kristianstads län, Villands häradsrätts domboksrenovationer, vol. EVIIAAAK:I2, 23 October I697, p. 99 verso; 2 February I700, no. 5I, pp. IO-II, Riksarkivet Vadstena landsarkiv (VaLA).

I7 Oppmanna församlings arkiv, räkenskaper för kyrka I705, vol. Lr:I; Vånga församlings arkiv, räkenskaper för kyrka 1708, vol. Li:I (LLA). 
I8 Göta hovrätts arkiv, Advokatfiskalen Kristianstads län, Villands häradsrätts domboksrenovationer, vol. EVIIAABB:I20, 4 March I7ı2, no. 26 (VaLA).

I9 Debt litigations were common in the eighteenth century. See, for example, Maria Ågren, "Att lösa ekonomiska tvister - domstolarnas främsta sysselsättning på I70o-talet?", (Svensk) Historisk Tidskrift, I998, no. 4, pp. 48I-510.

20 Villands häradsrätts arkiv, domböcker vid lagtima ting I729, vol. Ara:24, I March I729, no. 57, and 3 March I729, addition to no. 57 (LLA). Cf. Perlinge 2005, p. 285, footnote 73.

2I Villands häradsrätts arkiv, upprops- och stämningslistor I723-I74I, vol. CV:I (LLA). Nine credits are unspecified, the average is thus estimated.

22 Villands häradsrätts arkiv, domböcker vid lagtima ting 1732, vol. Ara:25, 4 February I732; ibid. I744, vol. Ara:36, ir June I744, no. 33 (LLA).

23 Villands häradsrätts arkiv, domböcker/saköreslängder vid urtima ting I732, vol. Ara:25, 26 May 1732 (LLA).

24 Oppmanna församlings arkiv, död- och begravningsböcker I744, vol. Cr:3, p. I80 (LLA). Swedish transcription in part by Demografisk Databas Södra Sverige. See http://www. ddss.nu (accessed I8 June 2019).

25 Hanssen 1952 , p. 43.

26 Villands häradsrätts arkiv, bouppteckningar 1744, vol. FIIa:5, no. 36/37 (LLA). No probate inventory was made after the wives. His son, Jon Truedsson, had taken over the farm in 1729 .

27 Villands häradsrätts arkiv, upprops- och stämningslistor I728-I736, vol. CV:I (LLA).

28 Oppmanna församlings arkiv, död- och begravningsböcker 1743 , vol. Cr:3, p. 177 verso (LLA).

29 Villands häradsrätts arkiv, bouppteckningar I744, vol. FIIa:5, no. 50 (LLA).

30 Villands häradsrätts arkiv, bouppteckningar I766, vol. FIIa:I6, no. 38 (LLA).

3I Öller I967 (I800), pp. I27-I28. Author's translation and modernisation of the language. It has been assumed that Öller in this case had personal knowledge about the acclaimed prosperous farmer in Jämshög, which he also claims in the text. See Maria Adolfsson, Fädernelandets beskrivning: Om svenska ortbeskrivningsprojekt och ämbetsmäns folklivsskildringar under I700- och I80o-talet, Stockholm 2000, p. 237.

32 Jöns Ljungh, Fjelkinge i forna dagar. Historiska och genealogiska anteckningar: Bidrag till en sockenbeskrivning, Helsingborg 1904, p. IOI.

33 Villands häradsrätts arkiv, bouppteckningar 175I, vol. FIIa:8, no. 3 (LLA). After his second wife, Elna Persdotter, no probate inventory was made. However, the probate inventory after Håkan Holm in 1752 does not disclose any extraordinary wealth: a gross wealth of $2,362 \mathrm{dsm}$ and debts amounting to $173 \mathrm{dsm}$. One single claim concerned the disposal of real estate worth I,ooo dsm. Villands häradsrätts arkiv, bouppteckningar I75I-I753, vol. FIIa:8, no. 34 (LLA). Jon Truedsson and Hilla Catharina Kock married in 1755 . Could she have received an inheritance from elsewhere in the meantime or were considerable assets withheld from the probate inventory? Unless some private records can be found, this will simply remain unknown.

34 Oppmanna församlings arkiv, död- och begravningsböcker i766, vol. Cr:3, p. 263 (LLA).

35 Oppmanna församlings arkiv, död- och begravningsböcker 1770, vol. Cr:4, p. 22 (LLA). There is no probate inventory to be found after Hilla Catharina Kock.

36 Oppmanna församlings arkiv, dödböcker i769, vol. Cr:4, p. I6 (LLA).

37 Villands häradsrätts arkiv, bouppteckningar I769, vol. FIIa:I9, no. I5 (LLA).

38 Villands häradsrätts arkiv, bouppteckningar I794, vol. FIIa:44, no. 69 (LLA). Appraisals 
made in riksdaler specie converted into daler silvermynt $(d s m)$ by using the formal exchange rate $\mathrm{r}: 6$.

39 Villands häradsrätts arkiv, bouppteckningar 1778, vol. FIIa:28, no. 25 (LLA).

40 Villands häradsrätts arkiv, bouppteckningar 1758, vol. FIIa:Io, no. 62 (LLA).

4I Villands häradsrätts arkiv, bouppteckningar 1794, vol. FIIa:44, no. 9I (LLA).

42 Villands häradsrätts arkiv, bouppteckningar I753, vol. FIIa:8, no. $5^{2}$ (LLA).

43 Nils Jönsson, "Ur Grönhults krönika: En skånsk lantmans dagbok för too år sedan under hembränningens glansperiod”, in Önnestads Elevförbunds Ärsbok 1932, p. 35; Perlinge 2010 .

44 Villands häradsrätts arkiv, bouppteckningar I775, vol. FIIa:25, no. 53 (LLA).

45 Villands häradsrätts arkiv, bouppteckningar $1745-48$, vol. FIIa:6, no. 2 (LLA).

46 Villands häradsrätts arkiv, bouppteckningar $\mathrm{77} 84$, vol. FIIa:34, no. 35 (LLA). 